\title{
PENGARUH PEMBERIAN FUNGI MIKORIZA ARBUSKULAR DAN KOMPOS KULIT BUAH KAKAO PADA PERTUMBUHAN BIBIT KAKAO (Theobroma cacao L.)
}

\author{
Ananda Y. Rahmayanti, Maria Viva Rini, M.A. Syamsul Arif \& Sri Yusnaini \\ Jurusan Agroteknologi, Fakultas Pertanian Universitas Lampung \\ Jl. Prof. Soemantri Brodjonegoro, No.1, Bandar Lampung 35145 \\ E-mail:nay_chowpz@yahoo.com
}

\begin{abstract}
ABSTRAK
Usaha pembibitan kakao yang dilakukan secara besar-besaran seringkali menghadapi masalah ketersediaan air penyiraman. Untuk mengatasi hal tersebut, pemberian Fungi Mikoriza Arbuskular (FMA) dan kompos kulit buah kakao (KKBK) dapat menjadi salah satu solusi dalam menyediakan air yang cukup bagi bibit kakao. Penelitian ini dilakukan bertujuan untuk mengetahui apakah aplikasi FMA dapat meningkatkan pertumbuhan bibit kakao, mengetahui bentuk respon bibit kakao terhadap pemberian KKBK, dan mengetahui apakah respon bibit kakao terhadap KKBK ditentukan oleh aplikasi FMA, (4) mengetahui dosis optimum KKBK bagi pertumbuhan bibit kakao yang diaplikasikan dengan FMA dan yang tidak diaplikasikan FMA. Penelitian ini dilaksanakan dari Bulan Desember 2011 sampai dengan September 2012 di rumah kaca dan Laboratorium Produksi Perkebunan Fakultas Pertanian, Universitas Lampung. Rancangan perlakuan disusun secara faktorial (2 x 5) dengan 4 ulangan. Faktor pertama adalah pemberian FMA dengan 2 taraf, yaitu $\mathrm{m}_{0}$ (tanpa FMA) dan $\mathrm{m}_{1}$ (diberi FMA). Faktor kedua adalah konsentrasi KKBK (v/v) dengan 5 taraf, yaitu $\mathrm{k}_{0}(0 \%), \mathrm{k}_{1}(5 \%), \mathrm{k}_{2}(10 \%), \mathrm{k}_{3}(15 \%)$, dan $\mathrm{k}_{4}(20 \%)$. Perlakuan diterapkan ke dalam satuan percobaan menurut rancangan kelompok teracak sempurna (RKTS). Homogenitas ragam data yang diperoleh diuji dengan Uji Bartlett, sedangkan untuk sifat kemenambahan diuji dengan Uji Tukey. Bila kedua uji tidak nyata, data dianalisis ragam. Pemisahan nilai tengah pada faktor pemberian FMA dilakukan dengan menggunakan Uji Beda Nyata Terkecil (BNT) pada taraf nyata 5\%. Sedangkan untuk faktor dosis kompos kulit buah kakao dilanjutkan dengan uji polinomial ortogonal pada taraf 5\%. Hasil penelitian menunjukkan bahwa FMA tidak mampu meningkatkan pertumbuhan bibit kakao, melainkan hanya meningkatkan persen infeksi akar oleh mikoriza saja. Dengan meningkatnya dosis kompos kulit buah kakao dalam media tanam, maka makin menekan pertumbuhan bibit kakao. Hal ini dapat dilihat dari peubah pengamatan tinggi bibit, jumlah daun, volume akar, bobot kering tajuk, dan bobot kering akar. Tidak terdapat interaksi antara pemberian FMA dan dosis kompos kulit buah kakao pada semua peubah yang diamati.
\end{abstract}

Kata kunci: Fungi mikoriza arbuskular(FMA), kompos kulit buah kakao, Theobroma cacao L.

\section{PENDAHULUAN}

Dalam pengembangannya, budidaya kakao di Indonesia mengalami peningkatan yang cukup pesat, baik dari segi perluasan areal maupun produksinya. Dengan semakin banyaknya produksi kakao tersebut maka akan semakin banyak pula produksi limbah kulit buah kakao yang berpotensi mencemari lingkungan. Akan tetapi, hal tersebut dapat diatasi dengan penanganan dan teknologi yang tepat sehingga limbah kakao tersebut dapat termanfaatkan.

Kandungan hara mineral kulit buah kakao cukup tinggi, khususnya hara kalium dan nitrogen. Dilaporkan bahwa $61 \%$ dari total nutrien buah kakao disimpan di dalam kulit buah. Kompos kulit buah kakao mempunyai pH 5,4; $\mathrm{N}$ total $1,30 \%$; C organik 33,71\%; $\mathrm{P}_{2} \mathrm{O}_{5} 0,186 \%$; $\mathrm{K}_{2} \mathrm{O} 5,5 \%$; $\mathrm{CaO} 0,23 \%$; dan $\mathrm{MgO}$ 0,59\% (Didiek dan Away, 2004).
Pada fase pembibitan, terdapat masalah kekurangan air. Untuk mengatasi hal tersebut, pemberian kompos kulit buah kakao dapat menjadi salah satu solusi dengan sifatnya yang memiliki daya serap air yang tinggi sehingga akan mampu menyediakan air yang cukup bagi bibit kakao. Selain itu, terdapat agen hayati yang juga mampu mengatasi masalah kekeringan pada tanaman yang dapat bersimbiosis dengan akar tanaman, yaitu fungi mikoriza.

Mikoriza berasal dari kata miches yang berarti fungi dan rhizoid yang berarti akar. Mikoriza adalah asosiasi simbiosis mutualisme antara fungi dan sistem perakaran tanaman tingkat tinggi (Rao, 1994). Dalam banyak asosiasi dengan mikoriza, fungi akan memperoleh senyawa karbon dari hasil fotosintesis tanaman inangnya. Sementara itu, menurut Sieverding dan Howeler (1986) dalam Aeni (2005), manfaat yang diperoleh tanaman inang dengan adanya asosiasi 
mikoriza yaitu meningkatkan serapan hara dari tanah ke dalam akar. Hasil penelitian yang dilakukan oleh Lucia, Yahya, dan Fakuara (1998) menunjukkan bahwa inokulasi fungi mikoriza pada tanaman kakao dapat menghasilkan pertumbuhan tanaman yang lebih baik. Inokulasi fungi mikoriza nyata mengefisienkan pemberian air pada pembibitan kakao.

Salah satu tipe mikoriza yang paling banyak ditemukan di alam adalah fungi mikoriza arbuskular (FMA) yang bersimbiosis dengan $\pm 80 \%$ spesies tanaman yang ada, baik yang dibudidayakan maupun yang tumbuh secara alami. Mekanisme hubungan antara FMA dengan akar tanaman dimulai dengan perkecambahan spora di dalam tanah. Tahap berikutnya yaitu FMA akan masuk ke dalam akar menembus atau melalui celah antar sel epidermis, kemudian hifa akan tersebar baik secara interseluler di dalam jaringan korteks sepanjang akar. Selanjutnya, hifa internal ini membentuk struktur yang disebut vesikel, yang berfungsi sebagai organ penyimpanan makanan atau berkembang menjadi klamidospora, yang berfungsi sebagai organ reproduksi (Simanungkalit, 2004).

Perbaikan teknik budidaya perlu dilakukan dengan menambah bahan organik pada media tanamnya. Saat ini petani cenderung memilih menggunakan pupuk kimia daripada menggunakan pupuk organik. Akibatnya, kandungan bahan organik tanah berkurang, kesuburan tanah menurun, hasil panen terus menurun. Salah satu cara untuk mengembalikan kondisi kesuburan tanah seperti semula adalah dengan menambahkan bahan organik berupa kompos ke tanah pertanian dan mengurangi penggunaan pupuk kimia.

Kompos kulit buah kakao mengandung unsur hara yang dibutuhkan oleh tanaman kakao. Mikoriza yang diaplikasikan juga dapat membantu dalam meningkatkan efisiensi penggunaan pupuk. Kombinasi keduanya diharapkan dapat memberikan hasil terbaik terhadap pertumbuhan bibit kakao, namun secara jelas belum diketahui dosis pupuk kompos pada pengaplikasian fungi mikoriza arbuskular yang efektif untuk mendapatkan hasil yang optimal. Oleh karena itu, pemberian FMA pada taraf dosis kompos kulit buah kakao diharapkan berinteraksi positif dalam meningkatkan pertumbuhan bibitkakao.

Penelitian ini dilakukan bertujuan untuk mengetahui apakah aplikasi fungi mikoriza arbuskular dapat meningkatkan pertumbuhan bibit kakao, mengetahui apakah respon bibit kakao terhadap kompos kulit buah kakao ditentukan oleh aplikasi FMA, dan mengetahui dosis optimum kompos kulit buah kakao bagi pertumbuhan bibit kakao yang diaplikasikan dengan FMA dan yang tidak diaplikasikan FMA.

\section{BAHAN DAN METODE}

Penelitian ini dilaksanakan dari Bulan Desember 2011 sampai dengan September 2012 di rumah kaca dan Laboratorium Produksi Perkebunan Fakultas Pertanian, Universitas Lampung.

Rancangan perlakuan disusun secara faktorial (2 x5) dengan 4 ulangan. Faktor pertama adalah pemberian FMA dengan 2 taraf, yaitu $\mathrm{m}_{0}$ (tanpa FMA) dan $\mathrm{m}_{1}$ (diberi FMA). Faktor kedua adalah konsentrasi KKBK dalam media tanam ( $\mathrm{v} / \mathrm{v})$ dengan 5 taraf, yaitu $\mathrm{k}_{0}(0 \%)$, $\mathrm{k}_{1}(5 \%), \mathrm{k}_{2}(10 \%), \mathrm{k}_{3}(15 \%)$, dan $\mathrm{k}_{4}(20 \%)$. Perlakuan diterapkan ke dalam satuan percobaan menurut rancangan kelompok teracak sempurna (RKTS). Homogenitas ragam data yang diperoleh diuji dengan Uji Bartlett, sedangkan untuk sifat kemenambahan data diuji dengan Uji Tukey. Bila kedua uji tidak nyata, data dianalisis ragam. Pemisahan nilai tengah pada faktor pemberian FMA dilakukan dengan menggunakan Uji Beda Nyata Terkecil (BNT) pada taraf nyata 5\%. Sedangkan untuk faktor dosis kompos kulit buah kakao dilanjutkan dengan uji polinomial ortogonal pada taraf $5 \%$.

Pada tahapan pembuatan kompos kulit buah kakao, limbah kakao dipotong-potong hingga homogen berukuran lebih kurang 2-5 $\mathrm{cm}^{2}$. Selanjutnya, limbah kakao sebanyak $300 \mathrm{~kg}$ disiram dengan $80 \mathrm{ml}$ EM4 yang telah dilarutkan dengan gula merah 300 gram dalam 20 liter air. Kemudian adonan tersebut ditutup dengan plastik. Adonan disimpan di ruang terbuka, tetapi tidak boleh terkena sinar matahari. Kompos telah matang setelah 2 bulan dengan kandungan $\mathrm{N}$-total $0,61 \%$, Ptotal 2,96\%, C-organik 10,03, $\mathrm{pH} 7,22$, dan $\mathrm{C} / \mathrm{N}$ rasio 16,61 .

Media tanam yang digunakan dalam bak penyemaian adalah pasir. Sebelum digunakan, pasir tersebut perlu disterilkan terlebih dahulu dengan menggunakan autoklaf, lalu dibuat lubang tanam dengan menggunakan jari, kemudian benih kakao disemai di bak semai.

Setelah bibit berumur 14 hari, bibit dipindahkan ke polybag yang telah disiapkan. Sebelum media dimasukkan ke dalam polybag, terlebih dahulu dibuat adonan media tanah pasir (1:1) dan kompos dalam bak besar sesuai dengan perlakuan. Pada perlakuan $\mathrm{k}_{0}$ (tanpa kompos), maka perbandingan tanah pasir: kompos adalah 1:0. Pada perlakuan $\mathrm{k}_{1}$, perbandungannya adalah 19:1. Pada perlakuan $\mathrm{k}_{2}$ perbandingannya adalah 9:1. Pada perlakuan $\mathrm{k}_{3}$ perbandingannya adalah 17:3. Sedangkan pada perlakuan $\mathrm{k}_{4}$ perbandingannya adalah 4:1. Media tersebut kemudian dicampur hingga merata (homogen). Setelah itu, media yang sudah homogen 
dimasukkan ke dalam polybag (ukuran $12 \times 19 \mathrm{~cm}$ ). Selanjutnya dibuat lubang tanam dengan ukuran panjang, lebar, dan tinggi sekitar $10 \mathrm{~cm}$. Dilanjutkan dengan pemberian FMA (campuran dari jenis Glomus sp., Gigaspora sp., dan Entrophospora sp.) dengan dosis 500 spora per polybag di dasar lubang tanam. Setelah itu, bibit diambil dari bak semai dan dipindahkan ke dalam polybag. Bibit ditanam dengan posisi tegak, kemudian ditutup kembali dengan tanah dan agak sedikit ditekan.

Pemeliharaan meliputi penyiraman, penyiangan gulma, dan pemupukan. Penyiraman dilakukan sebanyak 2 kali sehari. Penyiangan gulma dilakukan secara manual, sedangkan pemupukan dilakukan saat tanaman berumur 1 bulan dengan memberi pupuk NPK dengan dosis $1 \mathrm{~g}$ per bibit dan dilakukan setiap 1 bulan sekali setelah transplanting.

Pengukuran tinggi tanaman mulai dilakukan saat bibit berumur 4 minggu setelah transplanting sampai akhir penelitian (bibit berumur 4 bulan) dengan periode waktu 1 bulan antar pengukuran. Perhitungan jumlah daun mulai dilakukan saat bibit berumur 4 minggu setelah transplanting sampai akhir penelitian (bibit berumur 4 bulan) dengan periode waktu 1 bulan antar pengukuran. Volume akar diukur secara manual dan sederhana, yaitu dengan menghitung selisih volume air di dalam gelas ukur $500 \mathrm{ml}$ sebelum dan sesudah dimasukkan akar bibit kakao. Bobot kering tajuk dan bobot kering akar diukur pada setiap perlakuan dengan cara mengeringkan tajuk dan akar dalam oven yang bersuhu $70^{\circ} \mathrm{C}$ sampai bobotnya konstan, kemudian ditimbang. Kegiatan ini dilakukan pada saat tanaman berumur 4 bulan. Pengukuran persentase infeksi akar oleh FMA dilakukan dengan metode Kormanik dan McGraw (Brundett, Bougher, Dell, Grove, dan Malajczuk, 1996). Rumus yang digunakan untuk menghitung persen infeksi akar oleh FMA adalah:

$\%$ InfeksiAkar $=\frac{\sum \text { PositifTerinf } \text { eksi FMA }}{\text { Total Pengamatan }} \times 100 \%$

\section{HASIL DAN PEMBAHASAN}

Hasil analisis ragam menunjukkan bahwa pemberian Fungi Mikoriza Arbuskular (FMA) hanya berpengaruh nyata pada persen infeksi akar oleh FMA. Perlakuan dosis kompos kulit buah kakao berpengaruh nyata pada tinggi bibit, bobot kering tajuk, dan bobot kering akar. Tidak terdapat interaksi antara pemberian FMA dan dosis kompos kulit buah kakao pada semua peubah yang diamati (Tabel 1).

Hasil penelitian menunjukkan bahwa pemberian FMA secara nyata meningkatkan persen infeksi akar oleh mikoriza dengan persen infeksi sebesar $73,9 \%$ dan berbeda nyata dengan bibit yang tanpa FMA $(17,6 \%)$ (Tabel 2). Hal ini disebabkan karena FMA mampu berasosiasi dengan hampir $90 \%$ spesies tanaman tingkat tinggi (Cruz, Ishii, dan Kadoya, 2000). Akan tetapi, FMA tidak mampu meningkatkan pertumbuhan bibit kakao bila dilihat dari peubah tinggi tanaman, jumlah daun, volume akar, bobot kering tajuk, dan bobot kering akar. Hal ini dapat terjadi dimungkinkan karena kurangnya faktor kecocokan antara spesies FMA dengan tanaman inangnya. Berdasarkan hasil penelitian Muas, Anwarudin, dan Herizal (2002), persen infeksi yang tinggi ternyata tidak menjamin dapat memberikan hasil yang tinggi terhadap serapan hara dan bobot kering bibit manggis. Keefektifan FMA sangat ditentukan oleh kombinasi fungi dengan tanaman inang. Ketidakcocokan antara FMA yang diaplikasikan dengan bibit kakao pada penelitian ini dimungkinkan terjadi karena FMA yang digunakan diisolasi dari rizosfer kelapa sawit.

Terdapat kemungkinan lain penyebab dari tidak adanya pengaruh FMA terhadap pertumbuhan tanaman, yaitu tingkat kesuburan media tanam yang cukup tinggi sehingga menyebabkan pemberian FMA tidak berfungsi secara optimal. Hal ini diperkuat dari peubah yang diamati pada bibit tanpa FMA, yaitu tinggi tanaman yang ratarata berukuran $64,3 \mathrm{~cm}$ dan jumlah daun yang rata-rata sebanyak 21 helai. Sesuai dengan kriteria bibit kakao

Tabel 1. Rekapitulasi hasil analisis ragam data penelitian

\begin{tabular}{lccc}
\hline \multirow{2}{*}{ Variabel pengamatan } & \multicolumn{3}{c}{ Signifikansi } \\
\cline { 2 - 4 } & FMA $(\mathrm{M})$ & Kompos Kulit Kakao $(\mathrm{K})$ & $\mathrm{M} \mathrm{x} \mathrm{K}$ \\
\hline Tinggi tanaman & tn & $* *$ & tn \\
Jumlah daun & tn & tn & tn \\
Bobot kering tajuk & tn & $*$ & tn \\
Bobot kering akar & tn & tn & tn \\
Volume akar & tn & tn & tn \\
Persen infeksi akar & $* *$ & & \\
\hline
\end{tabular}

Keterangan: tn $=$ tidak nyata, $*=$ nyata pada $\alpha_{0,05}, * *=$ nyata pada $\alpha_{0,01}$. 
siap tanam yang dikemukakan oleh Rahardjo (2011), tinggi tanaman yang berukuran lebih dari $60 \mathrm{~cm}$ dan jumlah daun lebih dari 12 helai dapat dikatakan sebagai bibit kakao dengan kualitas baik. Menurut Suhardi (1989), kolonisasi akar oleh FMA akan maksimal pada tanah yang kondisinya kurang subur, dan lebih banyak terdapat pada akar-akar yang mengalami kekeringan daripada tempat yang terlalu banyak air.

Hasil uji polinomial ortogonal pada taraf 5\% menunjukkan bahwa kompos kulit buah kakao secara nyata menekan pertumbuhan bibit kakao bila dilihat dari peubah tinggi tanaman, jumlah daun, volume akar, bobot kering tajuk, dan bobot kering akar (Gambar 1-5).

Respon bibit kakao terhadap pemberian kompos kulit buah kakao bersifat linear negatif, artinya terjadi penekanan pertumbuhan bibit kakao seiring dengan meningkatnya dosis kompos kulit buah kakao. Hal ini dapat dilihat dari peubah tinggi tanaman, jumlah daun, volume akar, bobot kering tajuk, dan bobot kering akar yang memiliki koefisien korelasi (r) yang negatif (Gambar 1-5).

Terjadi pula perbedaan kondisi fisik daun bibit kakao antara bibit yang tidak diberi kompos dan yang diberi kompos dengan dosis tertinggi $(20 \%[\mathrm{v} / \mathrm{v}])$ (Gambar 6). Daun pada bibit kakao yang diberi kompos $20 \%$ (v/v) menunjukkan adanya nekrosis yang dimulai dari tepi daun pada daun tua, yang terjadi sangat cepat.

Menurut Figuera dan Janick (1993) yang dikutip oleh Sartini, Djide, dan Alam (2007), kulit buah kakao mengandung zat tanin. Tanin memiliki daya racun kuat (Green dan Corcoran, 1975 dalam Pramiadi dan Suyitno, 2008), dapat menghambat aktivitas enzim selulase, poligalakturonase, pepsin, proteinase, dehidrogenase dan dekarboksilase (Einhellig, 1995 dalam Pramiadi dan Suyitno, 2008). Oleh karena itu, maka dimungkinkan hal itulah yang menyebabkan kompos kulit buah kakao yang digunakan dapat meracuni dan menghambat pertumbuhan bibit kakao yang ditanam. Dengan meningkatnya dosis kompos kulit buah kakao pada penelitian ini, maka akan meningkatkan senyawa tanin yang berada pada media tanam bibit kakao, sehingga dapat berdampak negatif pada pertumbuhan bibit kakao.

Menurut Foth (1994), unsur N dan Mg merupakan unsur pokok pembentuk klorofil. Selain itu juga, $\mathrm{N}$ adalah unsur pokok dari protein, yang merupakan senyawa pembentuk enzim. Enzim berfungsi sebagai katalis

Tabel 2. Pengaruh FMA pada persen infeksi akar bibit kakao umur 4 BST.

\begin{tabular}{lc}
\hline Perlakuan & Persen infeksi akar \\
\hline Tanpa FMA & $17,6 \mathrm{a}$ \\
Dengan FMA & $73,9 \mathrm{~b}$ \\
\hline BNT & 7,7 \\
\hline
\end{tabular}

Keterangan: Angka yang diikuti oleh huruf yang sama tidak berbeda nyata berdasarkan uji BNT pada $\alpha_{0,05}$.

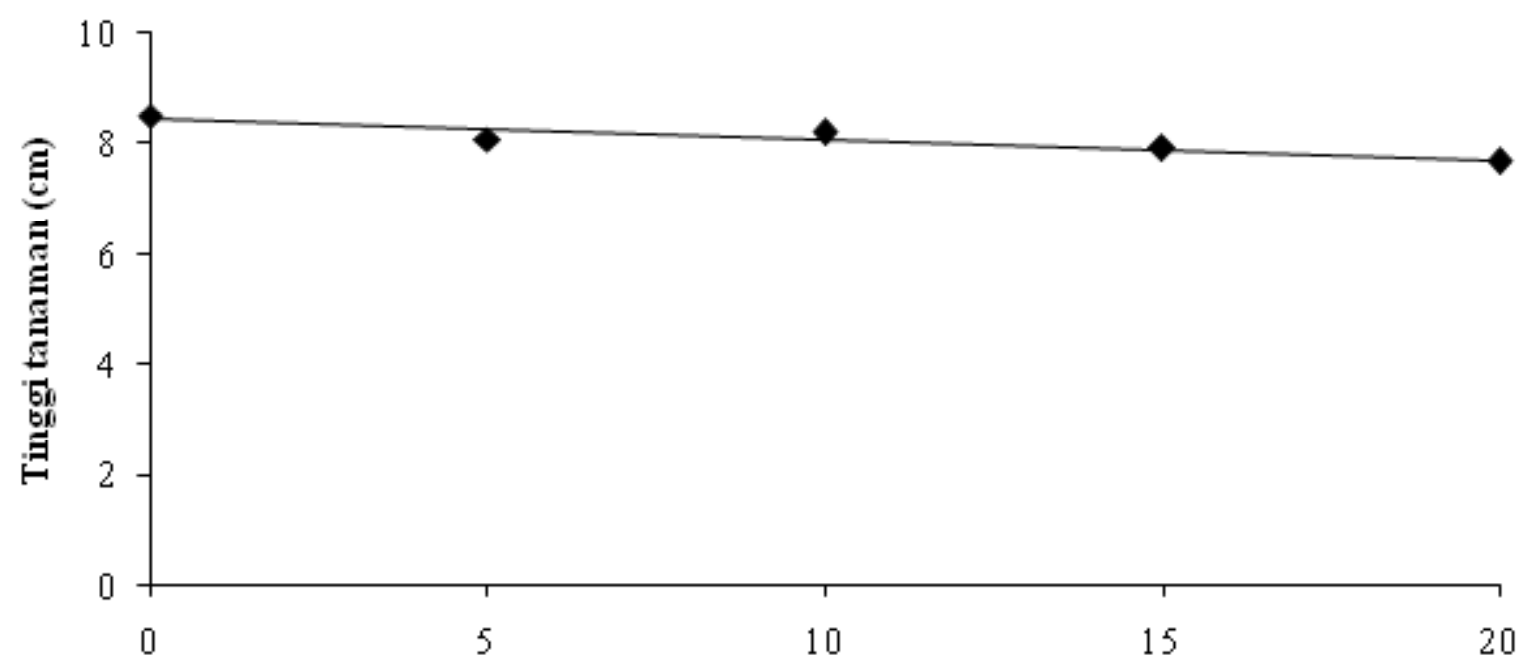

Dosis kompos kulit buah kakao (\%[v/v])

Gambar 1. Hubungan antara dosis KKBK dan tinggi bibit kakao umur 4 BST. $y=-0,04 x+8,43 ; R^{2}=-0,92^{*}$. 


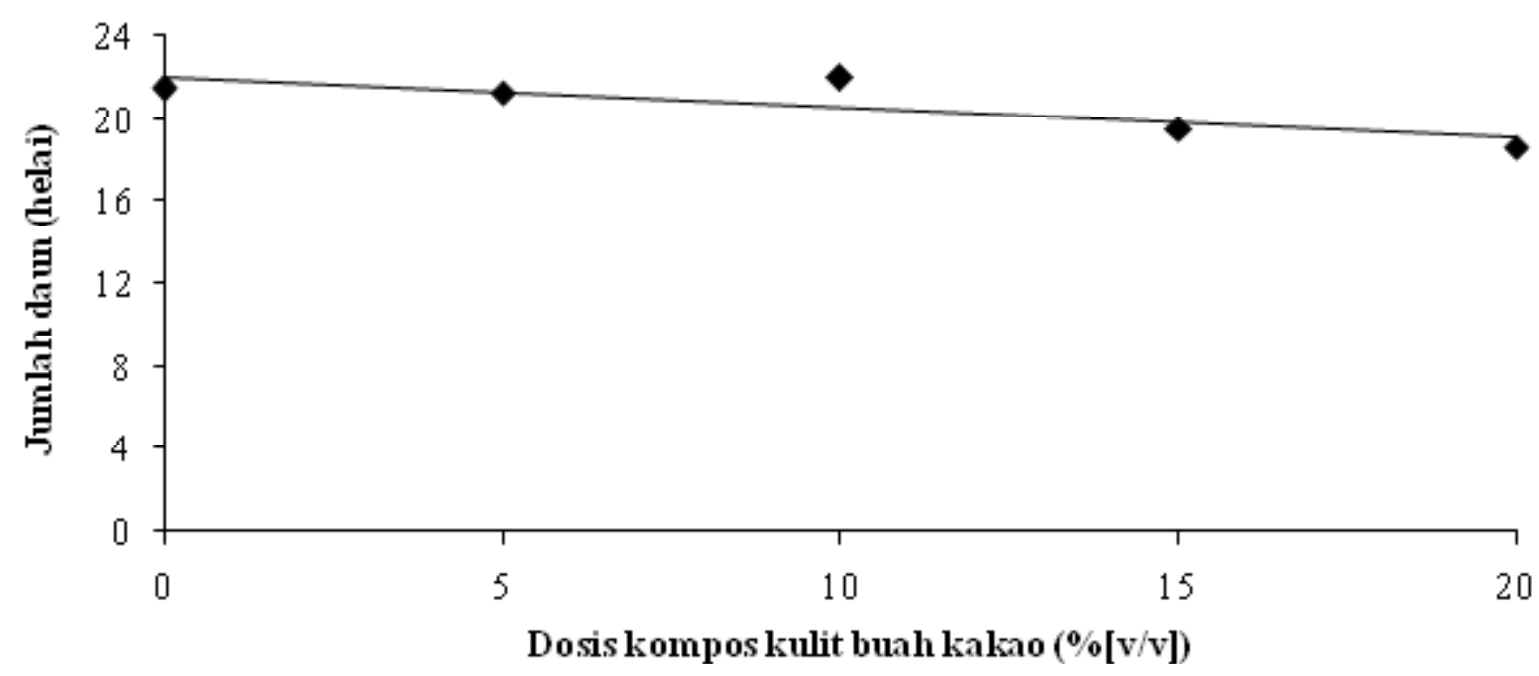

Gambar 2. Hubungan antara dosis KKBK dan jumlah daun bibit kakao umur 4 BST. $y=-0,15 x+22,08$; $\mathrm{R}^{2}=-0,82^{*}$.

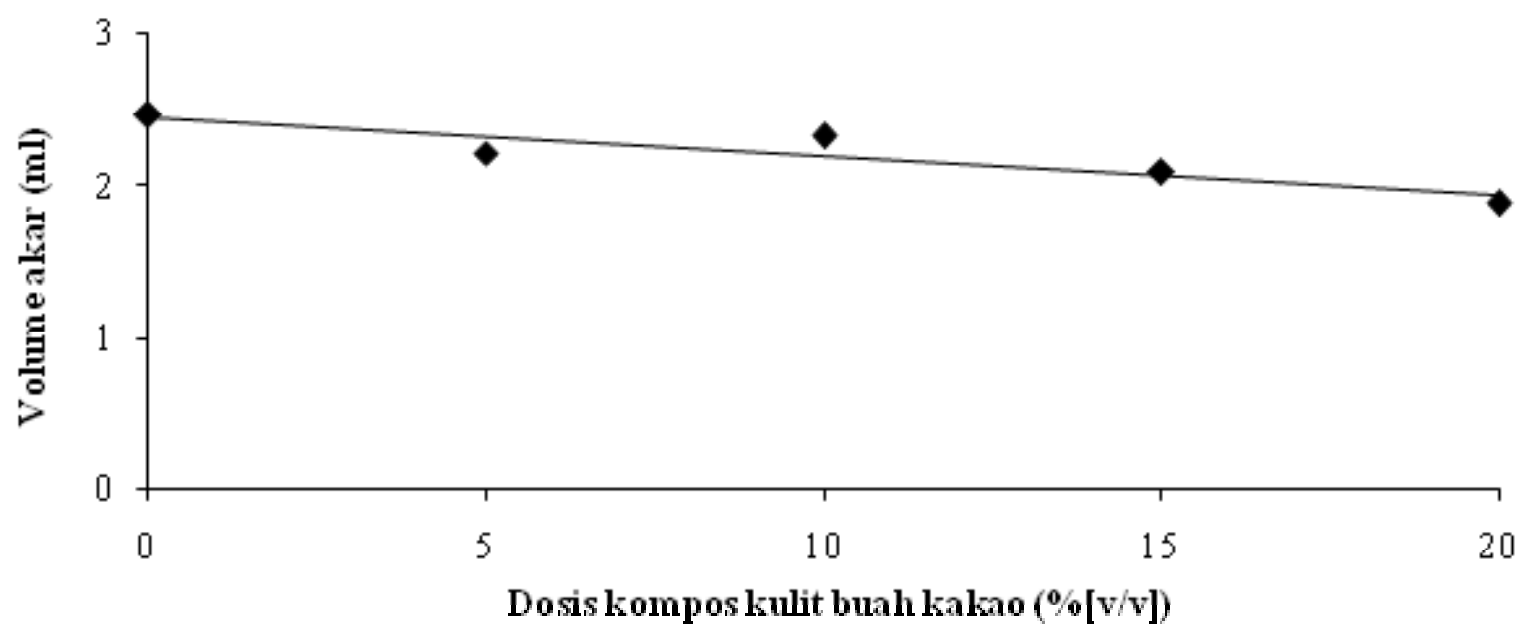

Gambar 3. Hubungan antara dosis KKBK dan volume akar bibit kakao umur 4 BST. $y=-0,03 x+2,45 ; R^{2}=-0,91^{*}$.

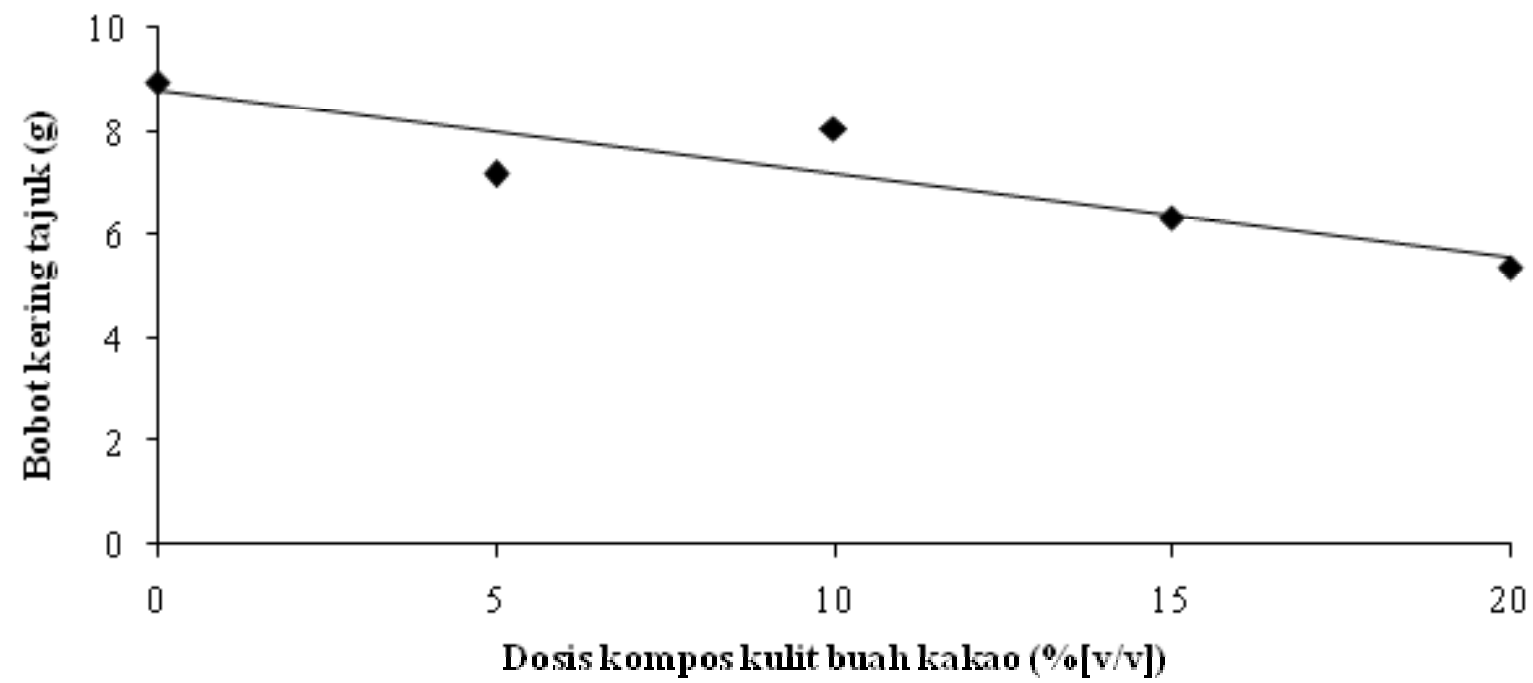

Gambar 4. Hubungan antara dosis KKBK dan bobot kering tajuk bibit kakao umur 4 BST. $y=-0,04 x+8,43$; $\mathrm{R}^{2}=-0,92^{*}$. 


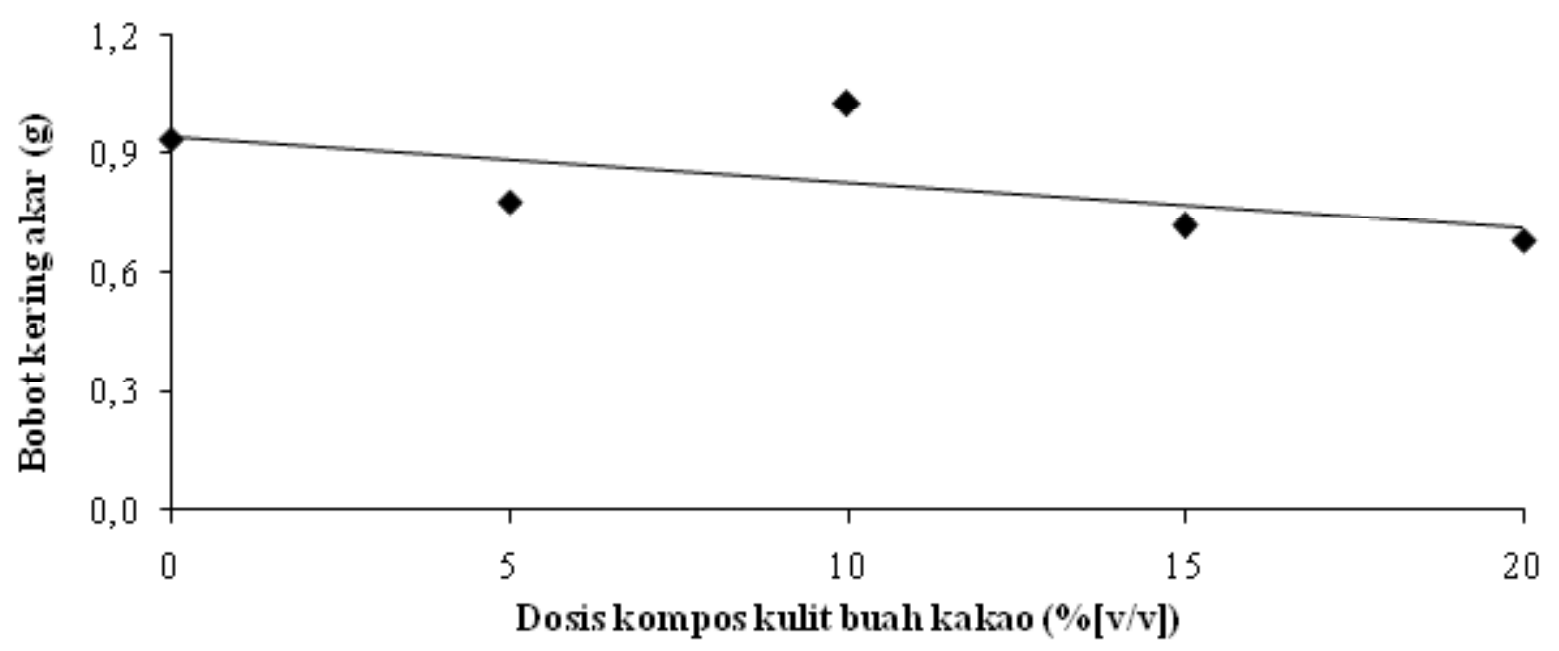

Gambar 5. Hubungan antara dosis KKBK dan bobot kering akar bibit kakao umur 4 BST. $y=-0,012 x+0,95$; $r=-0,61^{*}$.
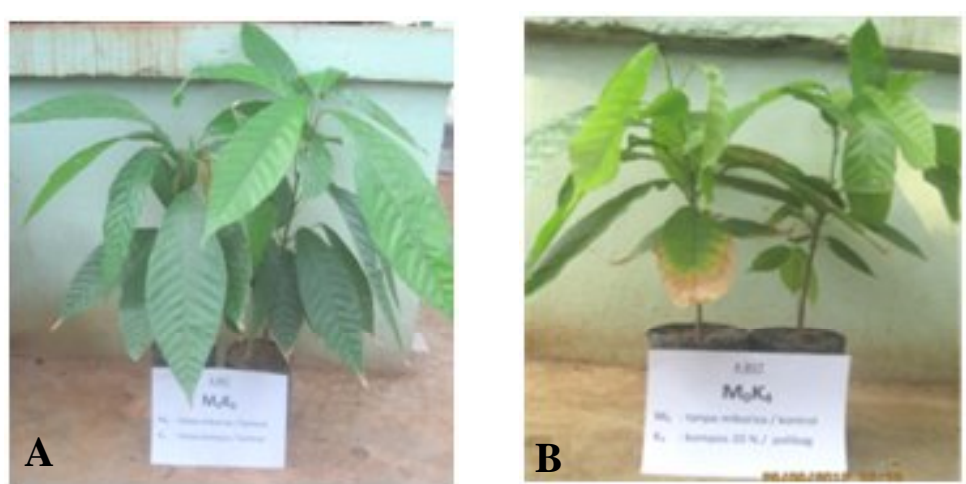

Gambar 6. Bibit tanpa KKBK (A) dan bibit yang diberi kompos kulit buah kakao dengan dosis 20\% (v/v) (B).

(mempercepat proses) dalam proses metabolisme tumbuhan. Diduga tanin dapat mengurangi penyerapan unsur $\mathrm{N}$ oleh tanaman sehingga tanaman mengalami kekahatan N. Dengan rendahnya unsur N dalam tanaman, maka akan menghambat pembentukan klorofil daun dan terhambatnya proses enzimatis tanaman. Hal ini memungkinkan terjadinya nekrosis pada daun dan terjadi penekanan pertumbuhan bibit kakao pada dosis KKBK tertinggi.

Interaksi yang tidak nyata antara pemberian FMA dan kompos kulit buah kakao pada semua peubah yang diamati menunjukkan bahwa FMA tidak mampu meningkatkan pertumbuhan bibit kakao pada semua dosis kompos kulit buah kakao.

\section{KESIMPULAN}

Dari hasil penelitian dapat dibuat disimpulkan bahwa pemberian FMA tidak mampu meningkatkan pertumbuhan bibit kakao, respon bibit kakao terhadap pemberian KKBK bersifat linear negatif, artinya terjadi penekanan pertumbuhan bibit kakao seiring dengan meningkatnya dosis kompos kulit buah kakao, respon bibit kakao terhadap pemberian KKBK juga tidak ditentukan oleh aplikasi FMA. Dosis KKBK optimum yang menghasilkan pertumbuhan bibit kakao terbaik adalah $0 \%$ (v/v) baik pada bibit ber-FMA maupun tanpa FMA.

\section{DAFTAR PUSTAKA}

Aeni, E. N. 2005. Pengaruh inokulasi cendawan mikoriza arbuskular (cma) dan fumigasi media terhadap pertumbuhan bibit kakao (Theobroma cacao L.). Skripsi. Universitas Lampung. Bandar Lampung. $58 \mathrm{hlm}$.

Brundrett M., Bougher N., Dell B, Grove T., and Malajczuk N., 1996. Working with mycorrhizas in forestry and agriculture. ACIAR Monograph 32. Canberra. $34 \mathrm{hlm}$. 
Cruz, A. F., T. Ishii, dan K. Kadoya. 2000. Effect of arbuscular mycorrhizal fungi on tree growth, leaf water potential, and levels of 1aminocyclopropane-1-carboxylic acid and ethylene in the roots of papaya under water stress conditions. Mycorrhiza J. 10(3):121-123.

Didiek, H.G. dan Y. Away. 2004. Orgadek: Aktivator Pengomposan. Pengembangan Hasil Penelitian Unit Penelitian Bioteknologi Perkebunan. Bogor. $87 \mathrm{hlm}$.

Ishzaloore. 2011. Penyakit tumbuhan. http:// ishzaloore.blogspot.com/2011/05/organismeyang-menyebabkan-penyakit.html. Diunduh tanggal 13 Desember 2012.

Lucia, Y., S. Yahya, M.Y. Fakuara. 1998. Efisiensi pemberian air pada bibit kakao yang diinokulasi cendawan mikoriza. Buletin Agronomi 26(1):1-8.

Muas, I., M.J. Anwarudin, dan Y. Herizal. 2002. Pengaruh inokulasi cendawan mikoriza arbuskula terhadap pertumbuhan bibit manggis. Jurnal Hortikultura 12(3):165-171. Balai Penelitian Tanaman Buah Solok. Solok. 7 hlm.

Pramiadi, D. dan Suyitno, A. I. 2008. Uji daya alelopati ekstrak daun kleresede (Gliricidia sp.)melalui bioassay perkecambahan dengan biji sawi (Brassica sp.) dan biji bayam (Amaranthus sp.). Makalah. Universitas Negeri Yogyakarta. Yogyakarta. $16 \mathrm{hlm}$.
Rahardjo, P. 2011. Menghasilkan Benih dan Bibit Kakao Unggul. Penebar Swadaya. Jakarta. 132 hlm.

Rao, N.S.S. 1994. Mikroorganisme Tanah dan Pertumbuhan Tanaman. Eds. 2. Universitas Indonesia Press. Jakarta. $353 \mathrm{hlm}$.

Sartini, M. N. Djide, dan G. Alam. 2007. Ekstraksi komponen bioaktif dari limbah kulit buah kakao dan pengaruhnya terhadap aktivitas antioksidan dan antimikroba. Jurnal Fakultas Farmasi Universitas Hasanudin. Universitas Hasanudin. Makassar. $7 \mathrm{hlm}$.

Simanungkalit, R.D.M. 2004. Fungi mikoriza arbuskular di bidang pertanian. Dalam Prosiding Workshop Mikoriza Teknik Produksi Bibit Tanaman Bermikoriza. Bogor. 13-15 Desember 2004. Hlm 13-16.

Suhardi. 1989. Mikoriza Vesikular Arbuskular (MVA). Pusat Antar Universitas (PAU) Bioteknologi UGM. Yogyakarta. $128 \mathrm{hlm}$. 